\title{
ZOË BOCCABELLA'S CALABRIAN CHAPTER IN MEZZA ITALIANA AS A SYMBOLIC ELIMINATION OF SOUTHERNESS FROM HER OWN DIASPORIC SELF
}

\section{O CAPÍTULO CALABRÊS DE ZOË BOCCABELLA EM MEZZA ITALIANA COMO ELIMINAÇÃO SIMBÓLICA DO SUL DA SUA PRÓPRIA IDENTIDADE DIASPÓRICA}

Teresa Di Somma ${ }^{1}$

Marcello Messina ${ }^{2}$

\begin{abstract}
:
In this work, we focus on the travel memoir Mezza Italiana (2011), written by Italian-Australian author Zoë Boccabella. Partly of Abruzzese and partly of Calabrian origins, she spends most of her trips to Italy in Abruzzo, only to stay very shortly in the Calabrian town of Palmi. Boccabella's narration of Calabria offers contestable representations of the region, as she conceals a sense of uneasiness at her own white privilege over Calabrians by means of a superficial and paternalistic outlook. Furthermore, taking Boccabella's journey as a starting point, we observe how Abruzzese identity is troubled by a desire to disavow its historical, cultural and linguistic affinities with the South of Italy, and by an urge to be considered part of the Centre. By recognising herself as mainly Abruzzese and minimising her Calabrian roots, we contend, Boccabella aims to "acquire full citizenship" not only within the Italian nation, but also within Australia.
\end{abstract}

\section{KEYWORDS:}

Australia, Italy, Diaspora, Travel, Calabria

\section{RESUMO:}

Neste trabalho examinamos o relato de viagem Mezza Italiana (2011), escrito pela autora ítalo-australiana Zoë Boccabella. Em parte descendente da região do Abruzzo, e em parte de origem calabresa, ela passa a parte maior das suas viagens na Itália no Abruzzo, e só fica uns dias na Calábria. A narrativa de Boccabella sobre a Calábria oferece representações problemáticas da região, em quanto a autora esconde o incômodo derivado da percepção do seu próprio privilégio branco através de um olhar paternalístico e superficial. Além disso, a partir da viagem de Boccabella, observamos a maneira em que a identidade abruzzês é marcada pelo desejo de repudiar as próprias afinidades linguísticas, culturais e históricas com o Sul, para o Abruzzo ser considerado parte do Centro. Em reconhecer a si mesma como primeiramente abruzzês, e em minimizar a própria

1 Mestre em Línguas e Literaturas Modernas pela Università degli Studi di Torino (2009). Mestranda em Letras: Linguagem e Identidade, Universidade Federal do Acre. Bolsista Capes Demanda Social.

2 Doutor em Composição Musical pela University of Leeds (2013). Bolsista PNPD e Professor Colaborador do Programa de Pós-Graduação em Letras: Linguagem e Identidade da Universidade Federal do Acre. 
identidade calabrês, Boccabella pretende "ganhar a cidadania", não só da Itália, mas da Austrália também.

\section{PALAVRAS-CHAVE:}

Austrália, Itália, Diáspora, Viagem, Calábria

The Orient is watched, since its almost (but never quite) offensive behavior issues out of a reservoir of infinite peculiarity; the European, whose sensibility tours the Orient, is a watcher, never involved, always detached, always ready for new examples of what the Description de l'Egypte called "bizarre jouissance." The Orient becomes a living tableau of queerness (SAID, 2014, p. 103).

\section{Introduction}

$\mathrm{n}$ this work we intend 1 to problematize the vision of Calabria and the South in general in the memoir Mezza Italiana, written by Italian-Australian author Zoë Boccabella (2011). We believe that she characterises the region as a "living tableau of queerness", through an orientalistic gaze, as per Said's (2014) above-cited quote, and as per Lombroso's theories of criminal anthropology, which operated in Australia to identify and discriminate Southern Italian diasporic subjects
(PUGLIESE, 2002, p. 157). Based on autobiographical travel memories, the narrative of Mezza Italiana converges on the issues of the Italian diaspora in Australia and the momentary return of the diasporic subject to Italy. Boccabella documents the process whereby she constructs and acknowledges her Italian identity through two journeys to Italy in her early twenties and late thirties respectively.

Partly of Abruzzese and partly of Calabrian origins, the author spends most of her two trips to Italy in her paternal grandfather's hometown in Abruzzo. Abiding by her relatives' warnings on the dangerousness of the 'ndrangheta, ${ }^{3}$ she only ventures to Calabria once, and for only a few days:

Whenever I expressed interest in going to Nanna Francesca's birthplace, the Calabrian seaside town of Palmi, my grand parents'

3 The Calabrian mafia. 
protective wails of 'No! No!' went off like duplicate sirens. Three decades ago, they happened to be in Calabria when a nephew was kidnapped by what is largely termed 'the Mafia'. It is no secret that different areas in the south have mafia groups, such as Sicily's Cosa Nostra and Naples' Camorra. However, for the most part the Calabrese keep their silence about the 'ndrangheta, acting as though it does not exist, adding another dimension to the Calabrian proverb: Chi s'occupa coi i suoi propri affari, va continuare per cent'anni, 'Whoever occupies himself with his own affairs will live a hundred years' (BOCCABELLA, 2011, 15591564).

Boccabella's trip to Calabria is narrated in the chapter "Old (and New) Calabria”, which offers contestable representations of Calabria and the South in general, thickly veiled under a positivistic and orientalistic attitude. In this article, we claim that Boccabella conceals a sense of uneasiness at her own unconscious white privilege over Calabrians by means of a superficial and paternalistic outlook, which links her work to nineteenth century trav- el literature on Southern Italy (PUGLIESE, 2002) and on the Orient (SAID, 2014). It has been argued (DICKIE, 1994; GRIBAUDI, 1997) that the South of Italy is considered as Italy's Other, as its negation, in a way that could be assimilated to Orientalism (cf. SCHNEIDER, 1998).

Our intention in this article is to show Boccabella's articulation of the "governing topos in the racialised mapping of the Italian peninsula" (PUGLIESE, 2002, p. 155) that makes sense of the South as deploying "the loaded signifier 'Africa'” (PUGLIESE, 2008, p. 3). Boccabella, in the Abruzzese chapter "The Castle", mentions some nineteenth and early twentieth century British travel literature on Abruzzo. Avoiding criticising any demeaning representation, the author reports the racialising narrations of the British travellers, who describe Abruzzo through the perspective of the curious anthropologist. Among them, she reports some of D.H. Lawrence's comments on Abruzzo from Sea and Sardinia (1921), such as the follow- 
ing: "'Life is so primitive. [...] So pagan, so strangely heathen and half savage. And yet it is human life."' (BOCCABELLA, 550551). Boccabella's failure to criticise this type of narratives constitutes an implicit endorsement to such a positivistic and dehumanizing standpoint (DI SOMMA, 2016). What is more, she deliberately draws upon British travel literature in order to position herself as white. For instance, she mentions Estella Canziani's Through the Apennines and the Land of Abruzzi (1928), arguing that

When Canziani visited the Abruzzo in 1913, the locals were so staggered by her different clothes and hairstyle and the paler colour of her skin that they touched her in amazement, even wanting her to take off her hat and pull down her hair because they couldn't believe someone could look so unlike them. Perhaps the open stares and up-anddown looks we endure are a holdover from such sheltered times? (BOCCABELLA, 2011, 556-559).

By comparing her and her husband's condition to that of Canziani, apparently singled out because "of the paler colour of her skin", Boccabella is literally setting the melanic ground for her own declaration of whiteness over "the locals". This declaration of whiteness is facilitated by the feeling of unease she constantly expresses towards the stares of these same "locals". The tension with these stares builds up throughout the book: "as we drive past the piazza, a group of villagers all turn to stare" (BOCCABELLA, 2011, 312), "they keep pointing and seem to stare at my bare legs" (BOCCABELLA, 2011, 315), "as we walk out, weighed down with shopping, I can still sense eyes on my back. I feel my indignation rising" (BOCCABELLA, 2011, 1405), and so forth.

Drawing on Anne-Meike Fechter's work on white EuroAmerican expats in Jakarta, appropriately titled The "Other" stares back (2005), we argue that Boccabella's exasperation at the stares of the Abruzzese villagers is a consequence of her declaration of whiteness, a whiteness which is necessarily troubled by the anxiety of "un- 
marking its own markedness" (FECHTER, 2005, p. 101):

Expatriates' individual experiences of whiteness differ, as do the ways in which they are negotiated. But there is a common refusal to acknow ledge their racial particularity as whites. While being unsettled by the reconfiguration of their white identity, most do not recognise a possible parallel with that of "racial Others" in western countries. They refuse to see whiteness as anything other than the racial norm defending its naturalized dominance with the same strategies that they complain of being victim to. This adds a dimension to our conceptions of whiteness in complex rather than unipolar power situations. Contested situations show that "white dominance" is not to be taken for granted, but whilst "the Other" can challenge and disrupt, make more self-conscious, it does not overthrow or make selfreflexive entrenched white identities and their discursive resources (FECHTER, 2005, p. 101).

Boccabella does indeed defend her "naturalized dominance" when she pretends to be able to undisturbedly observe and represent the "living tableau of queerness" of
Southern Italy. What makes the looks of "the locals" in Abruzzo utterly unbearable for her is precisely the idea that the Other can stare back, observe and represent her in return. In this sense, Boccabella's indignation at the stares she and her husband receive is primarily a declaration of whiteness, intended precisely as a naturalised right to dominance.

However, we understand and acknowledge that Boccabella's indignation at being stared at is not just a marker of her declared whiteness, but is also caused by the feeling that she belongs to that place as much as "the locals". Commenting on one of the stares episodes, she writes: "to my surprise I want it to be known I am not a tourist, that my family are from here" (BOCCABELLA, 1405). Part of this willingness to be recognised as being "from here" is certainly ascribable to her coming to terms with her Italian roots, while part of it is also explainable as anxiety to not be labelled as "Other" as she does with Abruzzese. 
This complicated relationship with Abruzzo somewhat conflicts with a much less complicated relationship with Calabria. While the author makes (problematic) references to travel narrative on Abruzzo, she does not mention any literature on Calabria. If anything, the only history that the author acknowledges as belonging to Calabria and the South comes from the abundant record of Mafia stereotypes that is normally available to members of Anglophone societies, and which contributes to form a distortedly violent and racialised picture of Southern Italy. Part of these stereotypes come from the accounts of Boccabella's own family members, as shown above, and part of them come from the plethora of audiovisual representations offered by Hollywood movies alongside Italian cinema and so forth:

At reception a male attendant in his late forties greets us with a black eye, a piece of sticking plaster holding together the delicate curve of skin underneath. When we talk to him we pretend not to notice his eye. He recommends a restaurant for lunch on a lonely road many kilometres away and rasps, 'Tell them Ugo sent you.' I'm starting to feel like I'm in a bad gangster film. (BOCCABELLA, 2011, 16431646).

Here, we contend, the fear and disgust Boccabella experiences are not only ascribable to the aforementioned family accounts on kidnapped relatives, but are part of a larger pre-packed imagery that associates whatever type of social interaction in Calabria/ the South to illegal businesses, violence and corruption.

The active operation of these stereotypes, together with the absence of any other type of knowledge source on the place, makes the author's perception of Calabria and of (what she recognises as) the South even more problematic than that of Abruzzo, since she denies any form of past to the region, and therefore characterizes it as a "terra nullius", that the writer seems to be in the process of discovering, rendering it as a racialised "Other". Boccabella perpetrates against 
Calabria what Pugliese calls "white historicide" (PUGLIESE, 2007b): by not acknowledging the region's past, she makes use of a "Eurocentric historiography underpinned by discourses of whiteness" (PUGLIESE, 2007b). In other words, Boccabella uses the same logic of the conquerors of the South of Italy of 1861: she denies the South's history in order to judge it as a land to yet be discovered.

This same technique, among other things, was applied to Latin America, too, as argued by Mignolo (2005, p. 4): Boccabella imposes the white people's history symbolised by her own personal history (her memoir) over the narrative of the Calabrian people. These are "disqualified as human beings, as historical actors, and as capable of thinking and understanding" (MIGNOLO, 2005, p. 4): they are being considered as not belonging to history. This, according to Mignolo, is the process of the "coloniality of being" (MIGNOLO, 2005, p. 4), which was applied to the indigenous populations of the American continent by the European colonizers and Creole élites.

\section{The racialised South - a} "living tableau of queerness" Boccabella seems to be well aware of the race implications embedded in the North/South dichotomy in Italy. At the beginning of the chapter in question, "Old (and New) Calabria", she admits that her grandparents did not want her to go to Calabria at all, because they considered it a dangerous place. As mentioned above, she reports their warnings about some family members who had trouble with 'ndrangheta, about a relative who was kidnapped and yet another who was shot dead for not paying the pizzo ${ }^{4}$.

Far from intending to question the authenticity of these lamentable episodes, we are interested in assessing how they operate towards the imprinting of a prejudice on Boccabella's conscience. We will do this by analysing the selection of anecdotes from

4 Pizzo refers to a sum of money business owners need to pay to the local criminal organization in Italy in turn of a protection of their establishment. In case they refuse 
her Calabrian journey that Boccabella includes in the book.

First of all, Boccabella dedicates an entire chapter to her trip to Palmi, her grandmother's seaside hometown. In Palmi, the author has an eerie adventure in a hotel, a place she sees as a "mafia stronghold" (BOCCABELLA, 2011, p. 1818). Boccabella admits she had pleasant experiences in other parts of Calabria, as briefly stated in the following passage: "but it is not Calabrian mafia clichés clouding our judgment. We stay in other towns and hotels in Calabria and never get the same feeling." (BOCCABELLA, 2011, 1818-1819).

However, in the book there is actually just one single mention of a positive experience on a short trip to Castrovillari, which is confined to a couple of paragraphs only (BOCCABELLA, 2011, 2260-2268). The simple fact that these "other towns and hotels" remain almost anonymous in the narration undoes her previous statement on not being influenced by mafia clichés: by choosing what not to tell, the author highlights what she is relating instead, silencing a positive narrative on the South that might have helped demystify the usual racist commonplaces. In fact, as Eni Orlandi puts it, silencing corresponds to censorship (ORLANDI, 1992, p. 101), and therefore we argue that silencing the positive aspects of Calabria generates a skewered negative view of the place.Drawing upon de Certeau (apud ORLANDI, 1992) and Žižek (2009), we consider her silence a direct influence of power's objective violent discourse, which operates by means of a peculiar silence (de Certeau apud Orlandi, 2011, p.101) and which does however not correspond to a lack of information per se. Censorship, according to Orlandi, operates at the level of meaning development, and works on the process of subject awareness towards it (ORLANDI, 2011, p. 101). Here the violent power in

to pay or decide to report it to the police, they could get their business damaged by the mafia. 
question is constituted by the discourse of the uniformizing white Italian nation, acting through a whitening historicidal "monologue"(PUGLIESE, 2007 b).

Therefore, before analysing what and how she narrates about the South, we want to draw attention to what she decides not to narrate and to the reasons behind that. On the one hand, it could be argued that she chooses Palmi as it is her grandmother's hometown, as a counterpart to the narration set in Fossa in Abruzzo in her grandfather's village, and avoids staying there longer due to the lack of a family home, which she can rely on in Fossa instead. On the other hand, however, the sparse positive experiences the author had in the small Calabrese village are narrated only briefly in just one paragraph.

These scarce serene moments, as briefly counted as they are, have her dare to think, for one moment, that her grandmother might have led a happy life in Palmi had she not migrated to Australia:
Seeing the current poverty and subjugation in the streets where Nanna Francesca grew up it is natural to feel grateful that my ancestors emigrated to seek out a 'better' life in Australia. And yet I feel hesitant in saying this. If I was born in Palmi I may have been very content with my lot in life, proud to live in this corner of Calabria. I think of the joyful shepherd I just saw, the smiling, chatty waiter with an Argentine wife whom we befriended, the shopkeeper who was so mortified she accidentally overcharged me when I bought several evil eye amulets and ceramics in her shop that she ran around the shelves to find us an item to take for free so we would not think badly of her. (BOCCABELLA, 1790-1795)

Here Boccabella very hastily, and therefore suspiciously in our view, withdraws her pejorative vision of Palmi, thanks to the encounter with a few congenial people, i.e. a (voiceless) shepherd,a waiter and a shopkeeper. The idea that her grandmother might have been content in Calabria contrasts forcibly with the rest of the narrative on Palmi. Certainly, Boccabella is attempting to engage and dialogue with her 
Calabrian counterparts, and they emerge as figures that somewhat contest the racist mafia stereotypes she has been so systematically prepared to confront, by her family and by the widespread audiovisual representations of the South she has been exposed to. On the other hand, however, we argue that the three nice people Boccabella meets only contribute to a positive experience because they are likely to stay in their place as subalterns. The shepherd, whose profession is almost extinct, is emblem of the alleged immobility of an inferiorised people such as the Calabrese; for being the most subaltern figure among the three, he is devoid of any voice, since any conversation the writer might have had with him is omitted. On the other hand, the congeniality of the waiter and shopkeeper contrasts starkly with the rough manners of the tending staff at the "mafia stronghold" (BOCCABELLA, 1814), that is, the Palmi hotel where Boccabella resides, which we will discuss below.
For now, we would just like to emphasize how the subaltern's complacency to hold on to the place assigned by society, thus acting according to the stereotypical requirements of their social role, is the only element that can contribute to a positive, though rapid and secondary, narration of the place.

When the expectations of docile subalternity that Boccabella reserves for good Calabrians are not met then, she starts talking of "mafia strongholds" and similar amenities. In the Palmi hotel where she stays with her husband, the reasons that make the author suspicious about the place are: the presence of security cameras; the extreme luxury of its interiors due to its glamorously decorated huge common rooms; its extensive pool in the outside area "luxuriously" covered in tiles and cement; and the fact that the author and her husband are the only guests for most of the time.

After sweltering days spent in Palmi's poverty-stricken 
streets it is a little bizarre to return at night to the grandiose hotel with its dozens of security cameras. Roger and I sit beside the huge pool (we are still the only guests). I have never gazed over literally hectares of cement and tile reeking of this excessive wealth. I don't really want to voice what I am thinking, certain it is my overactive imagination, but since Roger is more of a sceptic than me, I have to ask. 'Hey, you know with this hotel, do you ...?' '... get kind of a strange feeling about it?' he finishes for me. 'Yes, absolutely.' (BOCCABELLA, 2011, 1813-1817).

It is curious that a vast extension of tiles and cement is considered as a luxury, as in Italy these are very common architectural complements. This "luxury" is suspect to the point of being implicitly associated to mafia businesses on the Salerno-Reggio Calabria motorway:

It is not until 2010 that I come across a newspaper article detailing fifty-two arrests of the 'ndrangheta Calabrian mafia operating in and around Palmi. Among the multiple charges of mafia association, murder and extortion are allegations of infiltrating work contracts and collecting bribes in relation to the upgrade of the A3 autostrada between Salerno and Reggio Calabria - namely the '596 km of roadworks' we drove through to get here. The intimidation extended to supply of concrete from 'certain companies', which, considering the hectares of cement surrounding our hotel, is disturbing to say the least. (BOCCABELLA, 2011,1820-1824)

Leaving aside the utter preposterousness of Boccabella's homemade deductive investigation, whereby the simple interaction of "Calabrian-ness" with "luxury" seems sufficient to issue any sort of mafia allegations, here we want to focus on the total superficiality with which the phenomenology of Italian criminal organisations is dealt with. In Boccabella's book, in line with the most typical national/global regimes of representations, mafias cease to be a function of the complex imperial web of economic relations that subordinates the South to the North, and only become a matter of race and regional origin (cf. MESSINA, 2015). 
Back to the hotel in Palmi, the fact that all of that luxury is practically to the author and her husband's own use adds up to their uneasiness, and they feel particularly awkward with the staff members that attend them. One of them, a woman Boccabella renames as "Tough Cookie", is, according to the writer, over-muscular, and allegedly would be "more comfortable guarding a nightclub entrance." (BOCCABELLA, 1630-1631).

Here this lady's apparent deviancy from the gender stereotypes expected from a female caterer, represents the "shadow-beast" (ANZALDÚA, 1987) of Boccabella's patriarchal, heteronormative gaze, and is therefore objectified as an overbaked cookie, in order to be symbolically "digested" by the narrator. The waitress's appearance is linked to a non-standard sexuality: she is, to the eyes of the author, a queer individual whose aspect, due to the impossibility of an appropriate gender labelling, startles the narrator, who therefore associates her supposedly sexual deviancy to criminality. This happens in the same way as in the film Gomorrah, where the protagonists' queer homosocial relationship is implicitly linked to an allegedly innate tendency to criminality (MESSINA, 2015).

The waitress's prominent biceps, jet-black pony tail and damaged skin ("pock-marked", BOCCABELLA, 2011, 1631) add to a disturbing appearance at the eyes of the author, for defying the female prototype expected in patriarchal societies. Consequently, Boccabella diminishes this woman to the level of a food commodity, in order to be easily managed and disposed of. "Tough Cookie" is another of Perera's trophy bodies (PERERA, 2014, p. 2) subjugated and conquered through the action of renaming, because, as Mignolo explains, it is the colonizer's first performative act of exploitation (MIGNOLO, 2005, p. 3).The colonial power of renaming is a concept Boccabella is well aware of, as she criticizes how 
her grandaunt Soccorsa was renamed "Nancy" by hospital nurses in Australia when she was born:

Perhaps these Australians had good intentions behind 'renaming' someone's child but now, seven decades later, it reeks of imposed assimilation and arrogance. I could not imagine many Australians putting up with being told what to call their own child, even back then (BOCCABELLA, 2011, 15861588.

In the novel, furthermore, there is another instance of colonial renaming enacted by the author herself, who used to call her grandmother "nanna" instead of the Italian "nonna" against her will to tease her:

'Merry Christmas, Nanna.' 'I've told you! Call me Nonna!' she wails, as though mortally wounded. 'Nanna is more Australian.' This, I reason, is where we live after all. 'Mamma mia!' She throws up her hands and launches into a tirade of Italian directed at my father. (BOCCABELLA, 2011, 54-57).

The above quotes clearly exemplify

Boccabella's liminal identity, torn between blaming "these Australians" for renaming her own aunt, and calling her grandmother "nanna" as that "is more Australian". When it comes to "Tough Cookie", however, all this complexity disappears and the author seems to enjoy the power that renaming this waitress grants her.

Another male receptionist Boccabella feels uncomfortable with, as quoted above, has a black eye covered in a piece of plaster: when suggesting them a restaurant for dinner, he tells them to mention his name, which makes the author feel like "in a bad gangster film." (BOCCABELLA, 2011, 1645-1646).We would just like to underline that the fact of recommending a friend or relative's restaurant to tourists and asking to mention the recommender's name is a very common practice in the whole of Italy, especially in small villages as a way of exchanging favours, which does not have anything to do with criminal organizations. Anther detail which make the author believe the hotel is a backup for an 'ndrangheta business in the 
Salerno-Reggio Calabria road works is the fact that a staff is wearing a high-visibility jacket and that many "deeply tanned" (BOCCABELLA, 1626) male waiters have a heart tattoo on their forearm:

The strange thing is that each night there is just Roger and me at one table, several morose, standoffish waiters who outnumber us, and a different man eating solo at an adjacent table - just three diners. The men are deeply tanned. I observe that each one of them has the outline of a heart tattooed on his forearm. The atmosphere is tense (BOCCABELLA, 2011, 1624-1626).

Boccabella's description of this "mafia stronghold" is replete of melanic (the deep tan) and somatechnic ${ }^{5}$ (the heart tattoo) elements that profile the hotel staff as racialised suspects.The men described above have a dark complexion and are staring at the author and her husband; the muscular female attendant's hair is deeply dark; in the not-yet lit dining room, the first night, a waiter "appears out of the shadows behind us" (BOCCABELLA, 2011,1620-1621); a woman, similar in her build to her grandmother, watches her from a village house window "with a dark, suspicious look" (BOCCABELLA, 2011, 1701), just to mysteriously disappear behind a curtain.

This is also in line with the aforementioned orientalistic "living tableau of queerness"(SAID, 2014, p.103), that is to say, a collection of exotic peculiarities which satisfies the prejudgmental expectations of the Australian reader, whether of Italian origin or not. The "tableau of queerness" is populated by what Perera refers to as trophy-bodies (2014), bodies considered as "primitive" by D.H. Lawrence (apud BOCCABELLA, 2011, 550551), but "yet [...]human"(apud BOCCABELLA,2011, 551, our emphasis). This concession, this "yet", in fact fixes them as less human (or even non-human) than the Brits of D. H. Lawrence's times, or the Australians and the Northern/Centre Italians

5 'Somatechnics' refers to the intersectional space between the body as a merely physical phenomenon and the body as a purely discursive product (PUGLIESE \& STRYKER, 2009). 
of Boccabella's present epoch. These less-than-human trophybodies acquire almost animallike qualities "within [the] violent regimes of visibility and power" (PERERA, 2014, p.3)of the narrative disseminated by the international film industry. These trophy bodies are, according to Perera quoting Feldman, emblems of the nonhuman:

Governed by 'disidentification' rather than 'relations of resemblance' to the human, these emblematica of the nonhuman are characterized as a form of 'signification by fetishistic devices such as the grotesque, the monstrous, the bestial, the racially abject' (2010, p. 127). (PERERA, 2014, p. 2)

Using the above words in our context, we can assert that the less-than-human Calabrese bodies depicted by Boccabella are signified as monstrous and grotesque, as racial underdogs (PERERA, 2014, p. 2), in order to prevent the reader from identifying with them. As mentioned above, a similar kind of alienation occurs in the movie Gomorrah (GARRONE, 2008) where the representation of the protagonists' quasi-homoerotic bond, associated to their positionality as Neapolitans, concur to profile them as natural born criminals, with the result of alienating these characters from the spectator (MESSINA, 2015, p. 185).

Here Boccabella is literally reproducing the racialised representation of Calabrians as people of colour, as non-white, in keeping with the entrenched histories of racialisation that positioned Calabria as Calafrica, Saudi Calabria, and so forth. Importantly, as Pugliese puts it, this kind of racialised representations "both exploits and suppresses" the complex and rich nonEuropean genealogies that constitute Calabrian identity (PUGLIESE, 2007a). Boccabella does literally exploit and, at the same time, suppress these genealogies as an attempt to secure her own contestable hold on whiteness.

After all, Boccabella is well aware, as we mentioned above, of the contested status of her alleged whiteness. She 
herself has been an object of racism, primarily as a schoolkid labelled as a generic "wog" by Anglo-Celtic Australian kids:

When I sat down after the presentation, a girl sneered, 'Typical, another wog project from the wog.' I felt my cheeks turn a flaming pink and I vowed no matter how hard I had to fight my parents I would never do another project on anything remotely Italian again. In the playground, a boy spat biscuit in my face before running off and yelling, 'Wog!' On a different occasion, a boy tipped chocolate milk in my schoolbag and said my kind should go back to where we belonged, which confused me - I was born in Australia. Another time, a girl cried, 'Dirty wog', and spat on me. I took out the little hankie Mum always tucked in my pocket and carefully wiped the spit from the front of my Catholic school uniform, making sure I got my tearfilled eyes under control before looking up. I did not say a word and was not about to give anyone satisfaction by crying. Mum told me 'sticks and stones ...' but I envied her having grown up with an Anglo-Australian name and looks. (BOCCABELLA, 2011, 130-136).

Furthermore,Boccabella is also aware of the racialisation of the South operated by the North. As a person of Southern Italian origins, she was racialised by some members of the expat Italian community:in Mezza Italiana, she recalls the disgust she faced when she mentioned her Calabrian origins to a group of Northern Italians, none of whom "had ever ventured farther south than Rome" (BOCCABELLA, 2011,1652).

I was once having dinner with some northern Italians who enquired about my Italian origins. While it seemed acceptable to come from the Abruzzo, when I mentioned my grandmother was from Calabria there was silence. One woman actually puckered up her face with distaste, which prickled me (BOCCABELLA, 2011,16501652).

Moreover, she adds a few more episodes of racial slurs against Southerners, pronounced by people who were neither of Italian origin nor had ever been in the South. For example, the author and her husband, had been "warned by people (often nonItalians who have never been here) that if we venture into 
Calabria our car will either be stripped or stolen overnight" (BOCCABELLA,1646-1647), an occurrence which, needless to say, never happens to them.

Further on the writer explains that "regional boundaries even extend all the way to Australia where Italians, especially the older migrants, continue to identify and judge based on loyalty to the region of Italy from where they originated" (BOCCABELLA, 2011,1781-1782), and then relates on how her Abruzzese Granddad used to deride his Calabrian wife for being a Southerner:"He joked about a 'northerner' marrying a 'southerner'"(BOCCABELLA, 2011,1785). In this situation, the expression "loyalty to the region of Italy from where they originated" is a clear euphemism for "racialisation of the South".

In fact, Boccabella only reports examples of Northerners (or Australians) insulting the South, but does not mention any prejudices on

6 Italian for "grandmother" the part of Southerners towards Northerners. Her grandmother responds to her husband's alleged "regional devotion" by simply using her "'we are not amused' look" (BOCCABELLA, 1785-1786), which elsew here the author describes, in a rather stereotyped fashion, as her "'Calabrese look'” (BOCCABELLA, 2011, 89, 1602), that is, "a glare that could burn through steel" (BOCCABELLA, 2011, 89). Boccabella's $n^{n} n^{6}$ communicates her dissatisfaction for being inferiorised as a Southerner by her husband without appealing to any regional slurs. In other words, the only manifestation in Boccabella's memoir of any resentment or reluctance on part of the Southerners towards Northerners is represented by a voiceless glare, an effective corporeal exercise of defiant agency that, however, does not constitute an insult against Northern identities and positionalities.

Boccabella does not fully acknowledge her multi-layered white privilege of being an Ital- 
ian Australian with Abruzzese origins over her own Southern counterpart. At the same time, she minimizes the racialisation on the Mezzogiorno by means of strategic euphemisms such as the abovementioned "loyalty to the region of Italy" (BOCCABELLA, 2011, 1781-1782) or by considering her grandfather's tease as an innocent joke. By minimizing the fact that he was slurring her grandmother for being a Southerner, and dismissing it as a trivial marital tease, the author does not take into account her nonno ${ }^{7}$ s fault as well as her own for stereotyping her nonna. This means that, as DiAngelo would put it, Boccabella is blaming "other "bad" white people"” (DIANGELO, 2010, p. 59) for the problem of "the real" racialisation of the South, which for her remains as an event genuinely "external" to her family.

Furthermore, by disguising internal Italian racial divides as simplistic devotion to one's regional origin, rather than considering the unidirectionality of North-
South racism, Boccabella expresses a partial judgment, typical of what DiAngelo calls "white fragility" (2010). As a matter of fact, in all the examples Boccabella mentions, the racialised victim always happens to be the Southerner at the hands of the Northerner. A racialising hierarchy operates in the Italian peninsula whereby Abruzzo, although being part of the South, is on the upper scale of the hierarchy to the other Southern regions, as we will further explain in the next section. In the light of this, Boccabella's autoproclaimed Italian identity is more related to her Abruzzese side: in fact, in a passage of the book she declares that she feels "more bound to the Abruzzo"(BOCCABELLA, 18071808).

\section{An aesthetics of cold}

The Abruzzo sits uneasily halfway up the calf of the boot in central Italy and with its mountainous, cooler climate is more in line with the northern regions. Nonno Anni used to group it in with the north primarily to tease Nanna Francesca. He joked

7 Italian for "grandfather" 
about a 'northerner' marrying a 'southerner' while Nanna Francesca gave her 'we are not amused' look. Then he'd laugh about needing to sleep with one eye open if he said anymore.

1783-1786)

The passage above shows how some narratives on the Abruzzese identity are troubled by a persistent desire to disavow the region's historical, linguistic and cultural affinities with the South of Italy. These narratives are both autochthonous and external, and normally assign to the Abruzzo a higher degree of assimilability to the Northern Italian norm than that of Calabria and the South. As clearly shown in one of the passages quoted above, at a dinner with Northern Italian expats in Italy, Boccabella mentions her Abruzzese origins, which seem to be regarded as "acceptable" 2011, 1651), and then mentions her Calabrian origins, which are met with awkward "silence" and even expressions of "distaste" by the commensals (BOCCABELLA, 2011, 16511652). Even if the Abruzzo is historically and geographically part of the South of Italy then, it enjoys a higher status than that of other Southern regions, such as Calabria. Eventually, Boccabella elaborates more on this internal hierarchy:

When Australian descendants of Italian migrants are asked which region they come from, I have observed many often name the region from where the paternal side of the family originates. I have done this too, perhaps citing the Abruzzo because it is where we still have the familial house. It is only in recent years that, when questioned about my Italian heritage, my prompt reply of 'the Abruzzo' has altered to include 'and Calabria'. The most common reaction I get to the Abruzzo is: 'Where's that?' and to Calabria: 'Ooh, the mafia'. (BOCCABELLA, 2011,16031607)

Here we find Boccabella's reasoning on "the region" of "the paternal side of the family" totally improbable: in fact, drawing on existentialist terminology, we see it as a paradigmatic instance of "bad faith" (cf. SARTRE, 1992, pp. 86-118). Boccabella deceives the reader and herself, by trying to convince everyone 
that her previous reticence as to her Calabrian origin is not a political choice, but just the consequence of a bizarre patriarchal habit. What, on the contrary, appears obvious to us is that she had always avoided to declare her Calabrian origins precisely in order to avoid being offended and racialised as a Southerner.

Obviously, this bad faith is linked with an urge to be recognised as part of the Centre/ North, a desire that responds precisely to the national othering of the South. Avoiding to take a stance exclusively based on personal existential choices here, we situate our analysis within the complex discursive network of racialised power and assimilation that actually enables and constitutes her "choices" and thereby acknowledge the "torsions of violent contradictions" (PUGLIESE, 1995, p. 243) that pressure Boccabella - both as a "wog" in Anglo-Celtic white Australia, and as a "terrona" in Italy - to lean for the whiter parts of her identity.
Boccabella silences the similarities of Abruzzo with the South in order to focus on its climatological affinities with the North:

As we cross into the Abruzzo, the change in ambience is perceptible. The gentle, bosky hills and cultivated fields peter out in the face of imperious mountains. The Abruzzo is the stuff of fairytales castles surrendering to the elements and dark forests that still resonate with the enchantment of snake charmers, werewolves and witches. Rising arrestingly from the Adriatic Sea, the highest peaks of the Apennines, Gran Sasso and Maiella, are capped with snow, even in summer. Deep valleys and woods hide huge brown bears and roaming packs of wolves. The sheer, grey mountains tower like the walls of a mammoth fortress hiding all they encompass. No drawbridge is welcomingly lowered. (BOCCABELLA, 2011, 284-289).

Picturesque, fairy-tale descriptions like the above continue throughout the book. The cold high mountains of Abruzzo are the sign of a "change of ambience" from the typical Central/Southern Italian 
landscape, and this change produces enchantment and admiration in the protagonists:

As we speed across the valley floor towards Fossa, Roger and I exchange happy glances. I had forgotten how beautiful it is. This nook in the world is blessed. So much more beautiful in reality than in photos: the charm of Italian hill towns built of stone combine with the Alpine beauty of lush green fields and wildflowers. A backdrop of snow-capped mountains and clear blue skies is reminiscent of the pictures on old-fashioned Swiss chocolate-boxes. (BOCCABELLA, 2011, 9971000).

These enchanted descriptions echo the "aesthetics of cold" formulated by Southern Brazilian musician Vitor Ramil (2015). On the basis of the meteorological characteristics of the South of the country ${ }^{8}$, which are commonly perceived as an extreme exception in the general context of Brazilian hot weather, Ramil formulates a theory of gaucho milongas ${ }^{9}$ that is meant to oppose the hegemonic Brazilian tropical aesthetics. His urge to create a Southern Brazilian identity is troubled by a compelling necessity to escape Brazilian racialised identities:

Rio Grande do Sul's territorial extension equates approximately to that of Italy. Its people, the RioGrandenses, also known as gauchos, happen to feel like the most different in a country made of differences. This is mainly due to its condition of inhabitants of an important and unique frontier area, which they created and by which they were created (the state of Rio Grande do Sul has two frontiers with foreign countries of Spanish language); to the strong presence during its formation of European immigrants, who were mainly Italians and Germans; to a climate with distinctive seasons and to its past of wars and revolutions [...] (RAMIL, 2015, p. 7, our translation $)^{10}$

8 In Brazil North-South relationships are inverted in comparison to Italy, the North being poorer, warmer and racialised, and the South being temperate/cold, richer and predominantly white.

9 The milonga is a folkloric musical and dance style from the pampas of Southern Brazil (mainly from the State of Rio Grande do Sul), Uruguay and Argentina, whose inhabitants are commonly called gauchos. Cf Ramil (2015); Sosa (2010). The pampa is an expanse valley typical of the region.

10 A área territorial do Rio Grande do Sul equivale, aproximadamente, à da Itália. 
In the passage above the gauchos "happen to feel as the most different in a country made of differences" (RAMIL, 2015, p. 7): this, according to Ramil, is due to the supposedly exceptional peculiarity of the State of Rio Grande do Sul of lying in a frontier area and for having been colonised mainly by Italians and Germans. In other words, their uniqueness lies exactly on the "zero-point of orientation" (AHMED, 2007, p. 151) of its settlers. It is a type of "unique difference" which relies on the alleged uniqueness of the white body, exempt of any form of racialisation assigned to non-white bodies in racialising societies. This uniqueness lies in stark opposition to the type of difference of the racialised semi-naked bodies at the Carnival parade in the NorthEast of Brazil of which the musician makes mention:

I was having my mate ${ }^{11}$ while watching on the news some scenes of a belated Carnival parade in the North-East [of Brazil], a region where it is warm the whole year (Brazilian Carnival is a street festival which takes place in the whole country during the summer). The images showed a truck with a sound system surrounded by thousands of half-naked people dancing, singing and sweating underneath the heat of the sun. (RAMIL, 2015, p. 9). ${ }^{12}$

Exactly at this zero-point of Rio Grande do Sul's unique whiteness stand the Italians (mainly Northerners) and the Germans, who were welcomed in order to whiten the country

Sua gente, os rio-grandenses, também conhecidos como gaúchos, aparentam sentir-se os mais diferentes em um país feito de diferenças. Isso deve-se, em grande parte, à sua condição de habitantes de uma importante zona de fronteira, com características únicas, a qual formaram e pela qual foram formados (o estado possui duas fronteiras com países estrangeiros de língua espanhola); à forte presença do imigrante europeu, principalmente italiano e alemão, nesse processo de formação; ao clima de estações bem definidas e ao seu passado de guerras e revoluções [...]

11 Mate is a hot drink similar to green tea typical of the South of Brazil. Ramil makes a point on it because he is having it despite the fact that, at the time he is recalling, he was in Rio de Janeiro, where the climate is tropical.

12 "eu tomava meu chimarrão e assistia, em um jornal na televisão, à transmissão de cenas de um carnaval fora de época, no Nordeste, região em que faz calor o ano inteiro (o carnaval brasileiro é uma festa de rua que acontece em todo o país durante o verão). As imagens mostravam um caminhão de som que reunia à sua volta milhares de pessoas seminuas a dançar, cantar e suar sob sol forte." 
during the nineteenth and twentieth centuries, to enact a "moral and cultural hygienization of the Brazilian society" (PETEAN, 2012, p. 37) and who "created and were created by the frontier"(RAMIL, 2015 , p. 7), in a terra nullius. This whiteness is set against the racialised identities of NorthEastern Brazilians, with their semi-naked, sweaty parades and noisy sound systems.

In a similar way, the settlers of Acre, the Brazilian Amazonian state where we are writing from, created and were created by the frontier, forming a human barrier against Indigenous stateless populations and the racialised identities of Peruvians and Bolivians. However, due to Acre's settlers primarily nonwhite, non-purely-European identities (most of them came from the North-East of Brazil, the same area of the Carnival that Ramil describes), the "uniqueness" of Acre lies at the level of what Mignolo, Sakai, et al. call the racialised anthropos, whereas Rio Grande do Sul's represents universal humanitas:

As the historical evolution of anthropology suggests, humanitas has signified those people who could engage in knowledge production in both the first and the second relationships - namely, in the empirical as well as transcendental relationships, hence, empirico-transcendental doublet - while anthropos has gradually been reserved for people who participate in knowledge-production only in the first. Thus, humanity in the sense of humanitas has come to designate Western or European humanity, to be distinguished from the rest of humanity - so long as we trust in and insist upon the putative unity of the West (SAKAI, 2010, p. 455).

The contraposition of the tropical nakedness with the coldness of the gaucho land, we contend, is a euphemism for talking about a racial differential: in Ramil's words, "the cold is a big differential between us and the "Brazilians"13 (RAMIL, 2015 , p. 13), especially the racialised semi-naked bodies at the out of season Carnival parade in the North-East of Brazil. This insistence on the 13 "o frio é um grande diferencial entre nós e os "brasileiros"” 
cold climate, characteristic of the South of Brazil and extraneous to the rest of the country resembles Boccabella's positioning of Abruzzo in a zone of exception, whose "mountainous, cooler climate is more in line with the northern regions" (BOCCABELLA, 2011, 1778):

Whenever we first arrive in the Abruzzo, I feel the ambience transform. In the same way, the change in atmosphere when we leave is palpable. We shoot out of the last long, dark tunnel onto the other side of the mountains and into clement weather. The landscape returns to the gentle wooded hills and quaint cultivated scenery that Italy is renowned for. I look back. The Abruzzo is hidden by the enormous bleak mountains. A few dark storm clouds circle the peaks like ravens around castle turrets. I feel despondent. Judging by Roger's face as he glances over at me with a cheerless half-smile, he does too. We are happy about where we are going but sad about where we must leave (BOCCABELLA, 2011, 35083512)

Here we claim that Boccabella's climatological descriptions of the Abruzzo serve to mark a neat and clear distinction with Calabria:

It is a hot night, still $32^{\circ} \mathrm{C}$ at $9 \mathrm{pm}$. A little further on from where Roger and I sit, three elderly people open folding chairs and sit out in the narrow lane talking loudly. Across from them, another older couple perch on their front step shelling peas together. I would take a photo but Calabria is the one region in Italy where I've experienced extreme reluctance by most people even to be in the background of photos. (BOCCABELLA, 2011, 2265-2268)

Incidentally, in the last comment of the above quote it is interesting to note that Boccabella's unease at being observed by Italians clashes with her pretention to be able to photograph them undisturbed. In general, in Boccabella's descriptions as in Ramil's comments about the Brazilian North-East, the warm weather of Calabria frames bodies and behaviours marked by noisiness and disorder. Abruzzo stands as an exception, and in Fossa "streets are deserted, its inhabitants tucked up inside. It is spring but it is still cold". (BOCCABELLA, 2011, 30-31). 
Cold emerges as one of the discursive strategies that, not only in Boccabella's writings, produce autochthonous and external narratives of separation between the Abruzzo and the rest of Southern Italy, despite the linguistic, cultural and historical affinities that link these two cartographic entities.

For example, in 2013 a Facebook page was opened with the intent of slandering Southern students of the Department of Psychology of Chieti University (PAOLINI, 2013; ALEXANDRIS, 2013). On the page, an illustration read: "Abruzzese, please, don't leave us alone with the terroni" (ALEXANDRIS, 2013):

The anti-Southerner who created this page declares that the object of his disapproval is not only the geographical origin of the students - "even if", as he declares, "the role of geographical determinism is evident in shaping their inferiority" - but the fact that said students behave like "terroni, brawling, colourful and embarrassing creatures" (ALEXANDRIS, 2013) ${ }^{14}$
Here the racist representation of Southerners, perpetrated by the page administrator, is evidently fuelled by a perverse need of declaring himself, and Abruzzese in general, non-Southerners. The page was shut down after being reported to the police, and there is an abundance of similar manifestations. For example, in the Northern separatist online newspaper L'indipendenza nuo$v a$ a letter of an Abruzzese reader demanded not to consider Abruzzo as a Southern region, because, despite its historical legacy, it does not deserve the "gloomy destiny" which was reserved to the South of Italy:

When reading your newspaper, I always see my region assimilated to the south, and this bothers me, as no Abruzzese considers themselves a southerner, nor Abruzzo is part of the South. The South is understood as covering all the territories that are part of Objective $1,{ }^{15}$ and Abruzzo is not part of it; geographically, it is a central region; the same applies

14 "L’anti-meridionale ideatore della pagina definiscel'oggetto della sua disapprovazione non la mera provenienza degli iscritti 'anche se - si legge - è evidente il ruolo del determinismo geografico nella vostra scarsità' ma il fatto che tali studenti si comportino da 'terun, schiamazzanti e colorite creature imbarazzanti'”.

15 Objective 1, now called Convergence Objectives, is a EU structural funding project 
to economic, cultural and other parameters. I don't think that history, what is more, a forced history, can assign a gloomy destiny to a territory, such as the one that regards the Italian south. [...] Therefore, I would like to ask you to change the position of your newspapers as to the Abruzzo region, by situating it where it deserves to be, that is, in the Centre of Italy, as even Miglio ${ }^{16}$ used to maintain (L'INDIPENDENZA, 2012). ${ }^{17}$

This necessity to disavow Southern Italianness is far from exceptional. Cicirinella teneva teneva (TEQUILA E MONTEPULCIANO

BAND, 2013) is an Abruzzese version of the sixteenth century Neapolitan tarantella Cicerenella (DURANTE, 2015); its video seems to desperately pledge allegiance to normative Italianness against the renowned terrone origin of the song, by displaying in the background the horizontal stripes of the Italian flag. The video opens by declaring that "the cheerful hit Cicirinella teneva teneva has invaded the whole of Central Italy". ${ }^{18}$ By locating their own audience geographically in the Centre of Italy, Tequila e Montepulciano Band automatically disavow the very origin of the Neapolitan song they are singing.

Therefore, despite the Abruzzo, until Italian Unification (1860-61) was part of the Kingdom of the Two Sicilies, nowadays its belonging to the South is not consensually partaken by its inhabitants. In terms of Boccabella's work, she deploys the same discursive strategy of disavowal: in order to minimise her Calabrian roots, she privileges her Abruzzese

that covers all the regions, whose GDP per capita is lower than $75 \%$ of the EU average.

16 Gianfranco Miglio was a Federalist Northernist intellectual, associated to the Lega Nord.

17 "Leggendo il suo giornale vedo sempre la mia regione accostata al meridione, e me ne dispiaccio, visto che nessun abruzzese si sente meridionale, né l'Abruzzo è meridione (per meridione infatti si intendono i territori che appartengono all'Obiettivo 1, e l'Abruzzo non ne è parte, e geograficamente è una regione centrale, stesso discorso vale per i parametri economici, culturali etc..); non credo che la storia, per di più forzata, possa segregare un territorio ad un destino cupo, come quello che riguarda il meridione italiano [...] perciò volevo chiederLe di cambiare la posizione del suo giornale nei confronti della regione Abruzzo, collocandola dove merita, cioè nel Centro Italia, come anche Miglio diceva".

18 "Cicirinella teneva teneva, l'allegro tormentone, ha invaso tutto il Centro Italia" 
background. In light of the abovementioned pressure of the "assimiliationist torsion of contradictions" (PUGLIESE, 1995), she does so in order to acquire "full citizenship" within the Italian nation, which, in turn, allows her to acquire the same status in Australia.

The acquisition of "full citizenship" within Italy and Australia's immigrant community

We will start this section by juxtaposing a quote from Mezza italiana from the chapter "Beyond the Abruzzo":

In the Uffizi gallery, as I gaze at the artworks, I unexpectedly experience stirrings of pride. I have Italian blood in my veins. I am a part of this culture. It is all here, reflected in the art, in the scenes within the art, a civilisation and society thousands of years old. It is more than okay to be proud of it. In fact, it is a travesty not to be. Assimilation cannot prevail over a birthright. (BOCCABELLA, 2191-2193)

...with one from Joseph Pugliese's paper Noi altri: Italy's Other Geopolitical Identities, Racialised Genealogies and Inter-Cultural Histories (2007a):
The hegemonic images of Italianness, only ever couched in terms of the dominant Northern culture, can only ever signify kitsch: views of the Tuscan countryside; Michelangelo's David; the leaning Tower of Pisa and so on. All these images are caught within the kitschifying cultural economies of mass reproduction, dissemination and consumption. (PUGLIESE, 2007a, p. 187)

Pugliese's words, which seem to contradict Boccabella's "stirrings of pride" (BOCCABELLA, 2191) almost on purpose sarcastically, suit perfectly our view of the novel. It is indeed through the conceptual prism of the kitsch that we believe Boccabella's feelings of Italianness should be interpreted. The novelist has a sudden epiphany of Italianness only in Tuscany, when witnessing world-renowned Renaissance art.

This scene literally marks the embodied contradiction of this Southern diasporic subject caught in the double torsion of Anglo-Australian and Northern Italian assimilation. Here the "Italianness" of the Tuscan Renaissance art is assimilated to the cultural genealogy of 
Western humanitas in virtue of its deliberate display of whiteness:

Northern Italian high art was one of the few areas that possessed the sort of cultural capital, within the context of a self-obsessed and inward-looking Anglocentric culture, that allowed for a "legitimate" articulation of ethnic difference. Moreover, the dazzling white marble statue of David graphically signified Italiannes in terms of whiteness (PUGLIESE, 2007a, p. 187).

Northern Italian high culture, therefore, is the only way to convey an acceptable version of Italianness, as flagged by Pugliese in the context of Australian society. This same bias, we contend, operates to orientate Boccabella's narrative towards the assimilation to both Northern Italian and Anglo-Australian identities.

The novelist feels thrilled with her pictureperfect and over publicized Tuscan experiences, which, as the cheap plaster copy of the David (MEACHAM apud PUGLIESE, 2007 a, p. 185), reflect the commodification of Italian culture promoted by the Italian state and largely consumed abroad: "these are hegemonic images of Italianness" which "can only ever signify kitsch", as they "are caught within the kitschifying cultural economies of mass reproduction, dissemination and consumption" (PUGLIESE, 2007a, p. 188).

Here, with the signifier "kitsch" used by Pugliese, intended as "cheap", "distasteful", we would like to combine Milan Kundera's "kitsch", on which pivots the narration of The Unbearable Lightness of Being (1984): "Kitsch is the absolute denial of shit, in both the literal and the figurative senses of the word; kitsch excludes everything from its purview which is essentially unacceptable in human existence" (KUNDERA, 1984, p. 248).

Therefore, we claim that Boccabella's fervent identification with the Italian culture represented by the kitschy Tuscan commodified touristy sights, implies a total denial of all the "shit" behind it, including the 
gentrification of Florence historic centre and its sell-off to foreign capitals, all constituting a falsely tasteful makeup that conceals the exploitation and impoverishment of a part of its population. On a different level, this kitschy curtain dismisses also the "shit" that Boccabella has difficulty to identify with, i.e., "the poverty and subjugation in the streets" (BOCCABELLA, 2011, 1790) of Palmi, a poorer, less commodified area which is not adapted to the elitist tourist's palate.

We argue therefore, that through the denial of her Southern background, and the acceptance of Italy's kitsch, Boccabella desperately attempts to attain full citizenship both in Australia and in Italy.

Her otherwise ethnicised difference, thanks to the commercialisation of Italian high culture and cuisine, turns into a social advantage and therefore something to be proud of within her '“white Australian' identity" (BOCCABELLA, 3587), a label inscribed inside governmental demographic statistics that remains largely unproblematized by the author. Although she reports on various instances to have been insulted as a "wog" (BOCCABELLA, 182) during her school years in the 1970s and 1980s, Boccabella does not problematize the racial overtones of her identitarian background within her country, as historically Southern Italians were never fully signified as "white", neither in Australia (PUGLIESE, 2002) or the US (LUCONI, 2012).

Marked by the experience of racism as a "wog" in Australia, Boccabella resorts to identifying with the hegemonic vision of Italianness as white and Northern, in order to secure a "legitimate" identity within Australia. At the same time, she largely disavows her connection with Southern Italianness, seen as "dubious", "suspicious" and "impure".

\section{The Inferno-Paradiso dichotomy}

The creation of the writer's Northern Italian identity is therefore staged by labelling her Calabrian side 
as backwards, as shown in the following passages from her description of Palmi:"The lido is part Miami, part tropical isle, part Third World. Again, litter everywhere and grimy, outdated buildings. A shanty town of tin shacks lines part of the beach." (BOCCABELLA, 1743-1744), and:

Palmi feels oppressed, browbeaten. It is a beautiful spot with an amphitheatre of mountains surrounding a lovely stretch of beach and a clear sea. If the houses had been built into the cliffs instead of above them, it could have rivalled Positano. But it seems the spirit and progress of Palmi is being held under a thumb. (BOCCABELLA, 16601662)

In the first quote we identify the dichotomy heavenhell typical of colonialism and coloniality (MESSINA, 2016, p. 97), which reappears a few paragraphs further in the narration: "it is a poor area with dilapidated dwellings and the bitumen streets in poor shape, but the views of the lush mountains and the calm sea are magnificent" (BOCCABELLA, 1663-1664), where the extreme lavishness of nature is juxtaposed to the utmost misery of urban architecture. The two sides of this opposition "define and circumscribe the terms of [the colonial] discourse, being used as interchangeable instruments of domination" (MESSINA, 2016, p. 97, our translation).

These terms are essential to the hegemonic northwestern standpoint enunciated by Boccabella, which envisages all that is other-than-western as hopelessly underdeveloped, desperate, miserable and sad, as evident in the second quote: "it seems the spirit and progress of Palmi is being held under a thumb" (BOCCABELLA, 1662). This standpoint is precisely what has been criticised by Cassano (2001) in his "Southern thought", where he supports an epistemic revolution of the global South, capable of countering the hegemony of Northern-Western thought something on the same lines of the South-verting perspective of this special issue.

According to Cassano, "northwestern eyes [...] see 
the south as an anomaly, an anachronism, an accumulation of pathologies that will disappear only if and when the south becomes something other than itself - if and when becomes northwest" (CASSANO, 2001 , p. 2). Boccabella's view of the South, and particularly of Calabria, as a pathology, echoes Lombroso's pseudoscientific work, contained in his 1898 work In Calabria as mentioned by Pugliese (2002, p. 155): Pugliese points out that the phrenologist described his journey to Calabria as a descent to the Inferno, a voyage where he encountered barbarism, "unspeakable violence, savagery, decay, sickness, and physical and moral degeneration" (PUGLIESE, 2002, p. 155). Similarly, in his analysis of the discursive action of Lombrosian theories on the racialised narratives of the North-Eastern Brazilian subject, Durval Muniz de Albuquerque Júnior notices that

Life, in this region, always seems to be in danger, and seems to be participating in this very process of decomposition. Bodies, in line with Christian prophecy, all seems to be returning to the dust of the earth, mixing it with their corrosive fluids, that make it sterile. The death of human beings seems to sprout from the very death of the earth. The region, in these discourses, seems to have its shape and its organism mutilated and impoverished. Everything seems to fall apart around these subjects, who emit their literary discourse as the funeral eulogy of an entire people, an entire time, an entire space (ALBUQUERQUE JÚNIOR., 1997, pp. 95-96). ${ }^{19}$

Debunking these narratives of sickness and decay, it is indeed in a southverting sense that we criticise Boccabella's insistence on the idea of an impelling progress of humanity, the march of which is considered the final goal of a supposedly linear, empty, and homogenous history (BENJAMIN, 1993, p. 229). This limited perspective shapes the author's neo-colonialist view of Miami as a universal symbol of beauty and progress, as opposed to a generic and

19 "A vida, nesta região, parece estar sempre em perigo e ela própria parece participar 
racially charged idea of "Third World".

The picturesque Infernolike scenes that populate Boccabella's trip - literally, a descent - to Calabria, are curiously added flavour by juxtaposed culinary elements. In the enormous dark dining room where the waiter almost unexpectedly appears behind the protagonists, some dangerously spicy "spaghetti with garlic, olive oil and peperoncini" (2011, 1623-1624) are served, the recipe of which (BOCCABELLA, 2011, 1634) is inserted in the book right after "Tough Cookie" stares at them while serving breakfast. A scene with an old lady peering through the curtain, instead, is followed by the protagonists having some excellent espressos. It seems to us that the weirdest (according to the narrator) the happening, the tastier the food that follows, suggesting that as much as Calabrese food is spicy and savoury, so much is life in those areas unmeasured and immoderate, thus transforming Calabrese and Southern culture into a strange, colourful object to be observed and disposed of.

Importantly, in the Inferno/ Calabria, the predominance of dim ambiences populated by darker melanic types adds up to a racialisation of Southern subjects (PUGLIESE, 2008) which is absent from the chapters about Abruzzo, that, as abundantly mentioned above, is considered by the author as being culturally (and racially) closer to the North. Although the main characters receive continuous stares in Abruzzo as well, there these stares are not associated to gloomy and suspicious connotations, and are juxtaposed to picturesque descriptions. The only instance of a "dark, suspicious look" (BOCCABELLA, 318) in Abruzzo is the author's grandmother's. In Rome, on her way to Fossa

desse processo de decomposição. Os corpos, realizando a profecia cristã, parecem todos voltar ao pó da terra, a ela misturando seu líquido corrosivo que a faz estéril. A morte dos homens parece brotar da própria morte da terra. A região, nestes discursos, parece ter sua forma, seu organismo mutilado e depauperado. Tudo parece se precipitar à volta destes sujeitos, que emitem seu discurso literário como canto fúnebre de um povo, de um tempo, de um espaço". 
during her first trip, Boccabella even assists to a passer-by's death whose "lifeless blue eyes are staring towards" her (BOCCABELLA, 259-260), a scene which is provided with a transcendental feature which clearly contrasts with the almost demoniac ambiences and (living) people's manners the writer describes in Palmi. It is astonishing to us that the death of a man is not described as a grievous experience and/ or as a bad omen but as a cold, curious and almost epiphanic discovery of an unearthly dimension:

From my seat high up in the bus, it appears his lifeless blue eyes are staring towards me. It is the first time I have seen, in the flesh, someone who has died. I reflect that indeed the soul or something has left the body. The bus lumbers on as I ponder the unexpected news his loved ones will soon receive. Italy has me on my toes. (BOCCABELLA, 259262)

The sentence "Italy has me on my toes" adds a steel cold touch to an otherwise pitiable happening, a detached attitude typical of the positivistic rigour of a nineteenth century anthropologist of ethnicised cultures. A dead man in Rome gives the author a celestial stare, whilst her own Calabrian grandmother and many Palmi dwellers seem to look gloomily at her. Calabrians' demoniac looks are, in Boccabella's personal imagery, more sinister and disquieting than the very stare she astonishingly receives from a dead body.

In this sense, Calabrians, pretty much as the waitress renamed "Tough Cookie" represent, drawing again upon Glória Anzaldúa, Boccabella's "shadow-beast": the "strange", the "other", her "nightmarish pieces" (ANZALDÚA, 1987, p. 39).

We inscribe this into the uninterrupted, violent and steady process of historical annihilation, racialisation and ghettoisation of people of North African and Arabic origins in Calabria, which Pugliese describes as "white historicide" (2007b). Pugliese's effort to dignify centuries of denied history through the retrieval of shards, in this sense, is quite 
the opposite of Boccabella's stereotyped representation of Palmi and Calabria. Mezza Italiana sets the "far South" in an a-historical, unchanged, and unrealistic context, thus negating its right to existence. As argued by Mignolo, "colonization of being is nothing else than producing the idea that certain people do not belong to history - that they are non-beings" (MIGNOLO, 2005, p. 4).

This violent negation of history finds its climax in the book cover, decorated with a series of photos of knick-knacks that orientalise and commodify Italy. Among the various objects depicted in the book cover, for example, there is a wine cork with the Spanish writing "Tinto Reserva” (DI SOMMA, 2016, p.158). The superficiality with which Italy is represented by means of an object that does not obviously belong to it is symptomatic of the "historicidal erasure" (PUGLIESE, 2007b) of any difference between racialised communities.

If Calabria is an irredeemable Inferno, then, Italy is represented as a Paradiso through the kitschy mediation of Spanish wine corks, of postcard images, of white Renaissance statues, and of the "old-fashioned Swiss chocolateboxes" (BOCCABELLA, 2011, 999) that the author recalls when imagining Abruzzo.

\section{Conclusion}

In this paper,we have tried to analyse the orientalistic representations of Calabria in Boccabella's book Mezza Italiana. Influenced by the typical imagery of the Italian South, based on international mafia stereotypes, and subjugated by the monologue of the whitening Italian nation state, Boccabella fails to offer a convincing narrative of her coming to terms with her diasporic Southern Italian identity.Drawing on the work of Joseph Pugliese, we argued that such coming to terms could only be described, due to its hegemonic connotations, as kitsch. Glamourous and touristy parts of Italy stir sentiments of pride and cultural identification, whereas impoverished and 
racialised Calabria stimulates feelings of fear and even disgust, or, at most, a vague insecure acceptance.

Suspended between the violent pressure of both AngloAustralian and Northern Italian hegemonic forces, Boccabella fails to acknowledge her Southerness by means of a doubly articulated act of bad faith, which contemplates initially the assimilation of her Abruzzese identity to a non-suspect, legitimate Northern Italian background, and subsequently implies the negation of her Calabrian side, that remains the part of her identity which she has more difficulties in coming to terms with.

\section{However, Boccabella} is hardly unaware of the implications of both her positionalities as a wog in Anglo-Celtic Australia and as a terrona for internal and diasporic Northern Italians. On the contrary, as abundantly demonstrated in this paper, she carries a strong feeling of resentment against the (material and symbolic) racialised violence she has endured in her life. In this sense, her identification with Northern Italian kitschy iconography, with the fantasised, mountainous "Northerness" of Abruzzo, and her persistently unresolved relationship with Calabria cannot be read, if not as byproducts of the violence she is been repeatedly subjected to.

In this sense, we Southversively propose to reread the mezza ("half") of Mezza Italiana as the dramatic laceration, or the bisection of a subject that is literally rendered unable to come to terms with her own Italianness if not by leaving a portion of it outside, by eternally forgetting, neglecting, and symbolically eliminating, or neutralising, Southerness from the identitarian horizon of her own diasporic self. And it is again in a South-versive, openly polemical sense that we conclude that this is hardly a contradiction, within the violently racialised construct of Italy as a hegemonic notion that always already excludes 
the South from its discursive horizons.

\section{References}

AHMED, S. A phenomenology of whiteness. Feminist Theory, v. 8, n. 2, p. 149-168, 2007.

ALBUQUERQUE JUNIOR, D. M. D.Breve, lento, mas compensador: a construção do sujeito nordestino no discurso sócio-antropológico e biotipológico da década de trinta. Afro-Ásia, n. 19-20, 1997, p. 95107.

ALEXANDRIS, C. Ateneo Chieti: troppi 'terroni' alla d'Annunzio. Pagina Facebook scatena una guerra sul web. Abruzzoweb. 26/03/2013. <https://goo.gl/ BeMvmB>

ANZALDÚA, G. Borderlands/La Frontera: The New Mestiza. San Francisco: Aunt Lute Books, 1987 BENJAMIN, W. Magia e técnica, arte e política, São Paulo: Brasiliense, 1993.

BOCCABELLA, Z. Mezza Italiana: An Enchanting Story About Love, Family, La Dolce Vita and Finding Your Place in the World. Sydney: Harper Collins Australia. [Kindle edition]2011.

CANZIANI, Estella. Through the Apennines and the Lands of the Abruzzi. Cambridge:Heffer, \& Sons.1928.

CASSANO, F. Southern thought. In:Thesis Eleven,67, 2001, pp. 1-10.

CONRAD, J. Heart of Darkness. Boston; New York: Bedford; St
Martin's, 1996.

DIANGELO, R. White Fragility. The International Journal of Critical Pedagogy, v. 3, n. 3, pp. 54-70, 2011.

DICKIE, J. The South as Other: from Liberal Italy to the Lega Nord. The Italianist. 1994, 14: 124-140.

DI SOMMA, T. Recensione del romanzo "Mezza italiana" di Zoë Boccabella, Una italo-australiana alla riscoperta delle proprie origini tra orientalismo e snobismo "Bianco".Muiraquitã-revista de letras e humanidades, 2016, 4.1, <https://goo.gl/AecWc5>

DURANTE, F. I napoletani. Vicenza: Neri Pozza Editore, 2015. CAPOGRECO, S., MESSINA, M. As Masculinidades Queer das Periferias Globais:" Homem não chora" e "Maruzzella". Anais do Simpósio Linguagens e Identidades da/na Amazônia Sul-Ocidental, 2016, 1.

FECHTER, A. M. The 'Other' stares back: Experiencing whiteness in Jakarta. Ethnography, 2005, 6.1: 87-103.

GARRONE, M. Gomorra. Roma: Fandango, 2008. DVD

GRIBAUDI, G. Images of the South: The Mezzogiorno as seen by Insiders and Outsider. The New History of the Italian South: The Mezzogiorno Revisited, ed. by Robert Lumley and Jonathan Morris (Exeter: University of Exeter Press, 1997), 83-113.

KUNDERA, M. The Unbearable Lightness of Being, trans. Heim M. 
H. Harper \& Row, New York: 1984. LAWRENCE, D. H. Sea and Sardinia. Cambridge University Press: 2002.

LUCONI, S. L'identità etno-razziale degli italoamericani e il regime fascista. Parlare di razza - La lingua del colore tra Italia e Stati Uniti, Ombre Corte, Verona: 2012 MESSINA, M. Matteo Garrone's Gomorra: a politically incorrect use of Neapolitan identities and queer masculinities? gender/ sexuality/italy, $2015<$ https:// goo.gl/jEdhZ4>.

MESSINA, M. Atraso, Uwa'kürü - Dicionário Analítico 1, 96-106, 2016.

MIGNOLO, W. D. The Idea of Latin America.Malden; Oxford; Carlton: Blackwell, 2005.

MIGNOLO, W. D. Epistemic disobedience, independent thought and decolonial freedom. Theory, Culture \& Society, 2009, 26.7-8: 159-181.

ORLANDI, E. As formas do silencio. Unicamp, Campinas, Brasil, 1992.

OSSERVATORE

PADANO,

L'Abruzzo non merita di essere aggregato col Meridione d'Italia. L'indipendenza nuova. 12/10/2012 <https://goo.gl/ hh4ry4>

PAOLINI, M. Università Chieti: guerra agli studenti meridionali. Skuola.net, $16 / 04 / 2013$ <https://goo.gl/cNAnCj> PERERA, S. Dead exposures: trophy bodies and violent visibilities of the nonhuman. Borderlands, 13(1), 2014, p. 1-26.

PETEAN, A. C. L. O racismo universalista no Brasil: eugenia e higienização moral da sociedade. Cadernos de História, 2012, 3547.

PUGLIESE, J. Assimilation, unspeakable traces and the ontologies of nation. Meridian, 1995, 14.2: 229-254.

PUGLIESE, J. Noi altri: Italy's Other Geopolitical Identities, Racialised Genealogies and Inter-Cultural Histories. Literary and Social Diasporas: An Italian Australian Perspective, eds Gaetano Rando and Gerry Turcotte, Peter Lang, Bern, 2007 a, 185-202.

PUGLIESE, J. Race as category crisis: Whiteness and the Topical Assignation of Race. Social Semiotics, 12(2), 2002, 149-168. <https://goo.gl/ee9zvK>

PUGLIESE, J. White Historicide and the Returns of the Souths of the South. 2007 b. <https://goo.gl/ cWzz3D>

PUGLIESE, J. Whiteness and the Blackening of Italy: la guerra cafona, Extracommunitari and Provisional Street Justice. In: PORTAL Journal of Multidisciplinary International Studies, 2008. <http://goo.gl/ czE1tO>

RAMIL, V. A estética do frio.CEP, 2015, 96: 020-720.

SAID, E.W. Orientalism. New York: Vintage Books, Random House, 2014. 
SAKAI, N. Theory and Asian humanity: on the question of humanitas and anthropos. Postcolonial Studies, 2010, 13.4: 441-464.

SCHNEIDER, J. Italy's' Southern Question': Orientalism in one country. Bloomsbury Academic, 1998.

SOSA, M. M. Bebeto Alves e Vitor Ramil: rendimentos à milonga. Cadernos do IL, (41), 78-94, 2010. TEQUILA E MONTEPULCIANO BAND Cicirinella teneva teneva, 2013. <https://goo.gl/vjUUEr> ŽIŽEK, S. Violence: Six sideways reflections. London: Profile Books, 2009.

Data de recebimento: 05/12/2017

Data de aceite: 30/12/2017 